\title{
Evaluation of Ultrasound Pretreatment for Enhanced Anaerobic Digestion of Sida hermaphrodita
}

\author{
Kisielewska Marta ${ }^{1}$ (D) Rusanowska Paulina ${ }^{1} \cdot$ Dudek Magda $^{1} \cdot$ Nowicka Anna $^{1} \cdot \mathrm{Krzy}$ ik Aleksandra ${ }^{2}$. \\ Dębowski Marcin ${ }^{1} \cdot$ Joanna Kazimierowicz ${ }^{3} \cdot$ Zieliński Marcin $^{1}$
}

Published online: 26 February 2020

(C) The Author(s) 2020

\begin{abstract}
The influence of ultrasonic pretreatment with specific energy input ranging from 25 to $550 \mathrm{~kJ} / \mathrm{kg}$ volatile solids on the mixture of Sida hermaphrodita (L.) Rusby mixed with cattle manure disintegration and subsequent anaerobic digestion was assessed. The pretreatment process led to significant increase in the biomass solubility by $21.9 \%$ as chemical oxygen demand and enhanced biogas yield by $157 \%$ (567.1 L biogas $/ \mathrm{kg}$ volatile solids) when the specific energy input was from 200 to $550 \mathrm{~kJ} / \mathrm{kg}$. However, only pretreatments where ultrasound was applied at $25-50 \mathrm{~kJ} / \mathrm{kg}$ led to positive net energy gain, indicating that the biomass processing with this method does not always compensate the energy consumption for irradiation.
\end{abstract}

Keywords Lignocellulosic biomass $\cdot$ Perennial crop $\cdot$ Ultrasonication $\cdot$ Biogas $\cdot$ Methane $\cdot$ Biofuels

\section{Introduction}

Nowadays, biomass constitutes at least $8 \%$ of global primary energy supply in Europe [1]. However, the use of renewable energy sources should represent $20 \%$ by 2020 and $35 \%$ by 2050 [2]. The biomass potential for bioenergy production is affected by biomass supply and demand in various sectors of the economy, especially for the production of food, feed, fiber, and biochemical purposes. In consequence, the increasing attention is now being paid to search the non-food plant species in order to support biofuels production thus reducing the consumption of the food feedstock. The biomass of perennial herbaceous crops e.g., Sida hermaphrodita, Helianthus salicifolius, and Miscanthus $\times$ giganteus, offers a promising alternative to conventional energy crops for energy purposes

Kisielewska Marta

jedrzejewska@uwm.edu.pl

1 Department of Environmental Engineering, University of Warmia and Mazury in Olsztyn, Warszawska Str. 117A,

10-720 Olsztyn, Poland

2 Project Management Center, Czestochowa University of Technology, Dąbrowskiego Str. 69, 42-201 Czestochowa, Poland

3 Department of Water Supply and Sewerage, Bialystok University of Technology, Wiejska Str. 45E, 15-351 Bialystok, Poland
[3]. These plants are characterized by the high biomass yield, valuable biological composition, and low nutrient requirement, and thus can be grown on light soils with low organic matter and nutrient content, unusable for food or feed production $[4,5]$.

Out of many biological technologies, anaerobic digestion (AD) is the most cost-effective and widely used for commercial production of renewable energy from organic waste biomass $[6,7]$. The ratio of energy gain/input in $\mathrm{AD}$ was estimated at $28.8 \mathrm{MJ} / \mathrm{MJ}$, which is higher than for other biomass conversion technologies for energy production [8]. However, the direct utilization of lignocellulosic biomass for biogas production is limited because of the complex structure of the plant cell walls. Fermentable sugars of biomass carbohydrates such as cellulose and hemicellulose are trapped inside the crosslinking structure of the lignocellulose which is recalcitrant to biodegradation by enzymes and microbes [7]. Therefore, the pretreatment of biomass is always required to convert lignocellulosic material into a form amenable to biodegradation [9].

The pretreatment step is the most critical challenge for bioenergy production from lignocellulosic agricultural biomass due to the cost efficiency of the bioconversion processes [10]. As a result, the extensive research has been already done on lignocellulosic biomass pretreatment comprised of physical, chemical, and biological methods. As the result, the extensive research has been already done on lignocellulosic biomass pretreatment comprised of physical, chemical, and biological methods. Generally, all pretreatment methods are 
intended to decrease the crystallinity of cellulose, increase accessible surface area, and reduce lignin content, but not all of them have the positive effects on these factors. Chemical pretreatment methods including acid pretreatment, alkaline pretreatment, and ionic liquids improve the biodegradability of cellulose by delignification of cellulosic material, but they have a lesser impact on depolimerization and decreasing the crystallinity of cellulose complex [11]. The disadvantage of chemical pretreatment is the possible formation of harmful byproducts that can adversely affect anaerobic digestion and the cost of chemicals used for treatment [12]. Biological pretreatment is very slow and requires careful control of growth conditions and large amount of space for performing pretreatment [11]. Physical pretreatment methods such as mechanical, hydrothermal, ultrasonic, and microwave radiation pretreatments are effective at reducing the cellulose crystallinity, but they may generate inhibitory by-products [13]. The effects of different pretreatment techniques on the chemical composition and physical characteristics of lignocellulosic biomass have been summarized by Zheng et al. [7]. They stated that the choice of pretreatment method depends on the type of lignocellulosic biomass, and the best method is characterized by improving the digestibility of biomass for AD microbes, avoiding carbohydrate degradation and requiring minimal and inexpensive chemicals and low energy input. Thus, ultrasonic pretreatment is a promising solution due to the low investment and operational convenience [14].

In ultrasonic pretreatment (UP), ultrasound generates monolithic cavitation by passage of ultrasonic waves through the liquid medium, leading to many physical and chemical changes in the liquid solutions [8]. Cavitation is defined as the rapid formation, growth, and subsequent collapse of the bubbles; predominates at low frequencies $(<40 \mathrm{kHz})$; and causes an intense local heating (around $5000{ }^{\circ} \mathrm{C}$ ) and high pressure (around $50 \mathrm{Mpa}$ ) on a liquid/gas interface, turbulence, and high shearing phenomena in the liquid phase [15-17]. The extreme temperatures and pressures generated during cavitational collapse produce highly reactive free radicals $\left(\mathrm{H} \cdot, \mathrm{OH} \cdot \mathrm{HO}_{2}{ }^{\circ}\right)$, which facilitate chemical reactions of organic compounds in the liquid [16]. The cell wall structure of lignocellulosic biomass is disrupted due to the combined effects of both physical and chemical change, resulting in an increase in specific surface area, reducing the degree of polymerization, making cellulose more available to the enzymes through solubilization of hemicelluloses and lignin, eventually leading to the increase in biogas productivity by $4-83 \%[7,9,18,19]$.

Considering all of the above, the aim of the study was to determine the effects of ultrasonic pretreatment of the biomass Sida hermaphrodita on fermentative biogas and biomethane production. To the best of our knowledge, there is no study available in the literature focusing on correlating of biogas and methane outputs to composition of lignocellulosic agricultural feedstock and different ultrasonic pretreatment conditions.
Thus, a multiple regression model was used to predict energy gain based on experimental data.

\section{Materials and Methods}

\section{Substrate Origin and Characteristics}

In this study, the silage of Sida hermaphrodita (L.) Rusby mixed with cattle manure was used as a substrate for AD.

Sida hermaphrodita (L.) Rusby was cultivated in the Research and Experimental Station in Łężany of the University of Warmia and Mazury in Olsztyn (Poland), $\left(53^{\circ} 58^{\prime} 00^{\prime \prime} \mathrm{N}, 21^{\circ} 08^{\prime} 27^{\prime \prime} \mathrm{E}\right)$. No fertilizers were applied for the plant cultivation. The biomass was harvested in July of the second year of growing by a maize bale chopper, and subsequently ensiled with the bale silage process for 16 weeks.

The cattle manure produced by 360 head of dairy cattle was collected directly from the temporary field storage of solid manure located at the Research Station in Bałdy of the University of Warmia and Mazury in Olsztyn (Poland), $\left(53^{\circ} 36^{\prime} 01^{\prime \prime} \mathrm{N}, 20^{\circ} 36^{\prime} 14^{\prime \prime} \mathrm{E}\right)$.

Samples of silage of Sida and cattle manure were collected at five random locations, each in amount of $0.3 \mathrm{~kg}$ and then were transported on the same day to the laboratory. The plant material was mixed with cattle manure in weight-based ratio of $2: 1 \mathrm{w} / \mathrm{w}$ and hydrated with fresh water to obtain $90 \pm 0.4 \%$ hydratation. Two hundred fifty grams of a mixed sample was homogenized for $20 \mathrm{~min}$ (Robo 30, Germany) to obtain a homogeneous mixture with particle size of $\pm 3.0 \mathrm{~mm}$. The characteristics of a homogenized substrate are shown in Table 1.

\section{Pretreatment Equipment and Procedure}

Ultrasonic equipment used in this study was an ultrasonic horn (IS-1, InterSonic, Poland) with a power of $300 \mathrm{~W}$ and a frequency of $25 \mathrm{kHz}$. A volume of $1 \mathrm{~L}$ of homogenized sample was manually dosed in the ultrasonic horn. Subsequently, the pretreated sample was mixed with anaerobic inoculum and

Table 1 Characteristics of homogenized substrate

\begin{tabular}{ll}
\hline Component & Content \\
\hline Total solids (TS) & $18.9 \pm 2.1 \%$ \\
Volatile solids & $88.5 \pm 1.9 \% \mathrm{TS}$ \\
Total carbon & $45.6 \pm 1.8 \% \mathrm{TS}$ \\
Total nitrogen & $3.62 \pm 1.6 \% \mathrm{TS}$ \\
Cellulose & $8.82 \pm 1.5 \% \mathrm{TS}$ \\
Hemicellulose & $15.17 \pm 1.9 \% \mathrm{TS}$ \\
Lignin & $6.35 \pm 1.4 \% \mathrm{TS}$ \\
\hline
\end{tabular}


subjected to respirometric reactors. The experimental design is shown in Fig. 1.

The specific energy input $\left(\mathrm{E}_{\mathrm{S}}\right)$ was calculated as a function of ultrasonic power, the volume of sonicated substrate, and volatile solids (VS) concentration using the following equation:

$$
E_{S}(\mathrm{~kJ} / \mathrm{kg} \mathrm{VS})=P \cdot t / V \cdot V S
$$

where $P$ is the applied ultrasonic power in $\mathrm{kW}, t$ is the ultrasonic duration in seconds, $V$ is the volume of the substrate, and VS is the volatile solids concentration in $\mathrm{kg} / \mathrm{L}$. The setup pretreatment conditions are shown in Table 2. During UP, the increase of temperature created by cavitation was observed; thus, the thermal treatment was also carried out in experimental variants.

The energy output $\left(E_{\text {out }}\right)$ generated from biogas production was calculated using the following equation:

$E_{\text {out }}(\mathrm{kJ} / \mathrm{kg} \mathrm{VS})=Y_{\text {biogas }} \cdot y \mathrm{CH}_{4} \cdot E_{\mathrm{CH} 4}$

where $Y_{\text {biogas }}$ is biogas production in $\mathrm{L} / \mathrm{g}_{\mathrm{vs}}, y C H_{4}$ is the methane mole fraction in biogas, and $E_{C H 4}$ is the methane heating value in $\mathrm{kJ} / \mathrm{L}$. The net energy output $\left(E_{\text {nout }}\right)$ was calculated by subtracting the energy output in $n$-variant and the energy output in variant 1 (without pretreatment). The net energy gain $\left(E_{n e t}\right)$ was calculated by subtracting the net energy output
Table 2 Setup conditions during UP applied to homogenized substrate

\begin{tabular}{lll}
\hline Variant & $E_{S}(\mathrm{~kJ} / \mathrm{kg})$ & Treatment time (s) \\
\hline 1 & 0 & 0 \\
2 & 25 & 2 \\
3 & 50 & 4 \\
4 & 100 & 8 \\
5 & 200 & 16 \\
6 & 350 & 32 \\
7 & 550 & 64 \\
\hline
\end{tabular}

$\left(E_{\text {nout }}\right)$ and the energy input $\left(E_{s}\right)$.

\section{Batch Anaerobic Biodegradability Test}

Batch anaerobic biodegradability tests were conducted by using respirometric reactors (WTW GmbH, Germany). A single anaerobic reactor was consisted of the glass bottle with a working volume of $0.5 \mathrm{~L}$ coupled tightly with a cap, serving as a pressure sensor to determine the partial pressure increasing induced by biogas production. Pressure in the gaseous phase of the bottle was recorded every $15 \mathrm{~min}$. The respirometric system allowed determining the biogas production based on the pressure changes inside the bottle headspace on the basis
Fig. 1 Scheme of the experimental design

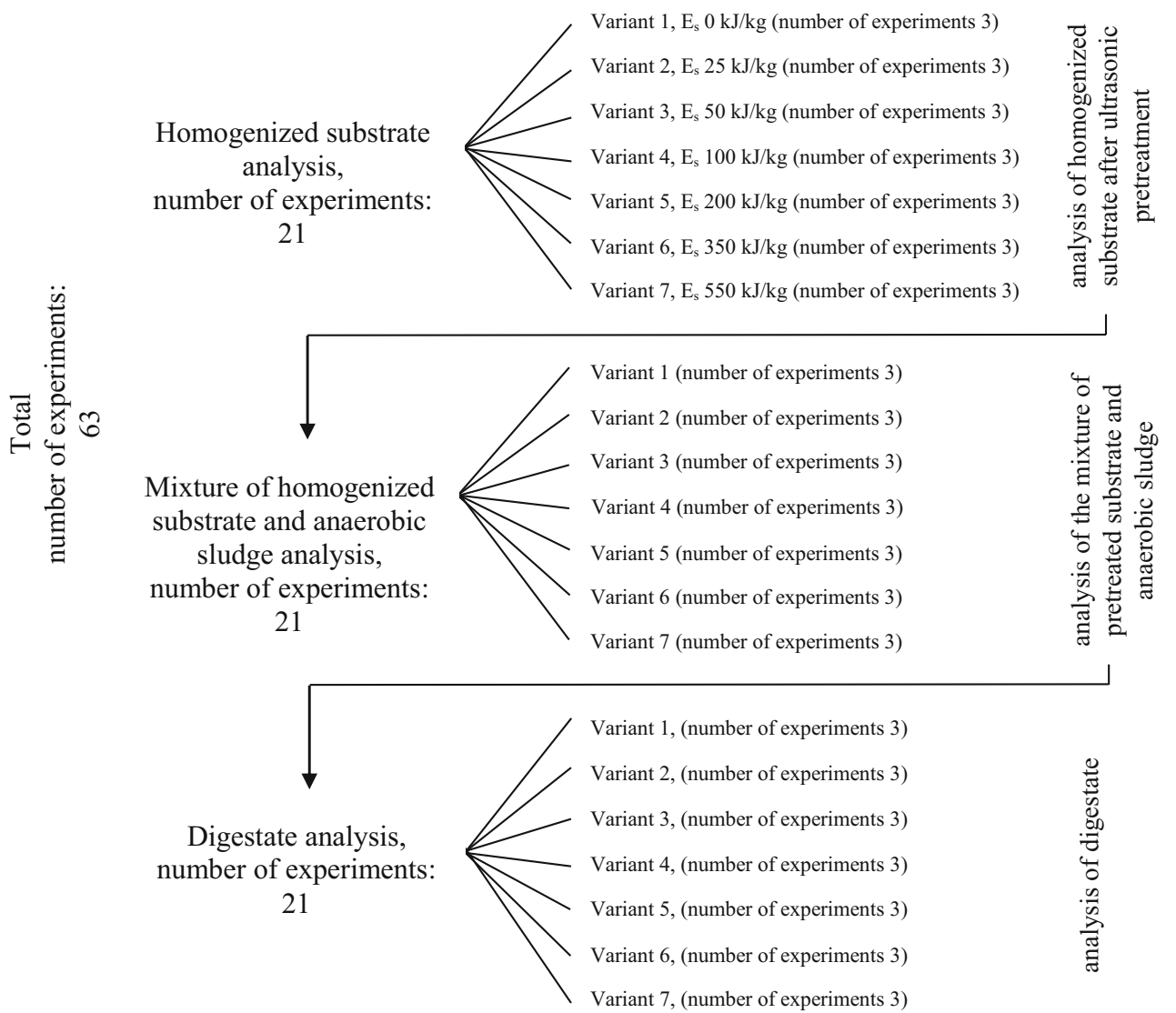


of an ideal gas equation. The tests were carried out at a constant temperature of $36 \pm 0.5^{\circ} \mathrm{C}$.

At the beginning of the tests, the respirometers were inoculated with $100 \mathrm{~mL}$ of anaerobic sludge. The inoculum was collected from agricultural biogas plant operated with liquid manure and crop residues. The main characteristics of the inoculum were total solids (TS) concentration $3.7 \pm 0.3 \%$, VS concentration of $69.2 \pm 2.8 \%$, and $\mathrm{pH} 7.57$. At the beginning of the tests, anaerobic conditions inside the reactors were met by blowing the bottles with nitrogen gas to remove atmospheric air. In all variants, the initial organic loading rate (OLR) was established on $5.0 \mathrm{~g} \mathrm{VS} / \mathrm{L}$. Batch anaerobic biodegradability tests were carried out for 40 days. All tests were run in triplicate.

\section{Analytical Methods}

The measurements of TS and VS were determined following the gravimetric method. In the solid fraction, the total carbon (TC) and total nitrogen (TN) were determined by elementary particle analyzer Flash 2000 (Thermo Scientific, USA). Soluble fraction (supernatant) for analysis was obtained after centrifugation (5000 rpm, $10 \mathrm{~min}$, MPW-251 Donserv, Poland). Total organic carbon (TOC) was determined in the soluble fraction by a TOC analyzer (TC $100 \mathrm{~L}$, Shimadzu, Japan). Chemical oxygen demand (COD) was determined in the soluble fraction using a DR 5000 spectrophotometer with an HT 200 s mineralizer (Hach-Lange, Germany). The cellulose, hemicellulose, and lignin contents were analyzed in the solid phase of homogenized samples after centrifugation (5000 rpm, $10 \mathrm{~min}, \mathrm{MPW}-251$ Donserv, Poland) by ANKOM 220 Fiber Analyzer (ANKOM Technology) with Van Soest method.

Methane content in biogas produced in the gaseous phase of the bottles was measured every $24 \mathrm{~h}$ using a gas chromatograph (GC, 7890A Agilent) with a thermal conductivity detector (TCD). The GC was fitted with the two Hayesep Q columns (80/100 mesh), two molecular sieve columns (60/ 80 mesh), and Porapak Q column (80/100) operating at a temperature of $70{ }^{\circ} \mathrm{C}$. The operational temperatures of the injection and detection ports were set on $150{ }^{\circ} \mathrm{C}$ and $250{ }^{\circ} \mathrm{C}$, respectively. Helium and argon were used as the carrier gases at a flow rate of $15 \mathrm{~mL} / \mathrm{min}$.

The formulas that can predict biogas and methane outputs depending on $\mathrm{E}_{\mathrm{s}}$ and the chemical parameters of lignocellulosic agricultural feedstock were developed during the study [20-22]. A multiple regression model using a stepwise progressive regression algorithm was used to identify the relevant predictor variables in the formulas, among the investigated variables by Statistica 12.0 PL package (Statsoft, Inc.). Then, the residual analyses were carried out to validate the regression models. The statistical results of the study were analyzed by Statistica 12.0 PL package (Statsoft, Inc.) with a
Shapiro-Wilk W-test. One-way analysis of variance (ANOVA) was applied to determine the significance of differences between variables. Variance homogeneity in groups was checked with a Levene's test, whereas the significance of differences between the analyzed variables was determined with a Tukey RIR test. In all tests, the level of significance was $\alpha=$ 0.05 .

\section{Results and Discussion}

\section{Effect of UP on Organic Matter Solubilization}

The COD and TOC represent the concentration of soluble organics, and the increase in these concentrations means that UP enhance the transfer of organic matter from lignocellulosic substrate into supernatant. The COD and TOC concentrations before pretreatment were $11,895 \mathrm{mg} / \mathrm{L}$ and $3856 \mathrm{mg} / \mathrm{L}$, respectively. Pretreatment of lignocellulosic substrate with ultrasonic irradiation provided the release of COD and TOC from the substrate and solubilization degree increased with the specific energy supplied $\left(E_{s}\right)$ (Figs. 2 and 3; Table 3), $(p<0.05)$. Maximum COD solubilization by $21.9 \%$ and TOC solubilization by $24.7 \%$ were reached with $E_{s}$ ranging from 200 to $550 \mathrm{~kJ} / \mathrm{kg}$. However, it was observed that with the highest specific energy input $\left(E_{s}\right)$, the solubilization rate slightly decreased. Pretreatment influenced the characteristics of the mixture of substrate and anaerobic sludge, in which an increase of COD and TOC content by respectively $9.9 \%$ and $11.0 \%$ with $E_{s}$ ranging between 200 and $550 \mathrm{~kJ} / \mathrm{kg}$ was observed (Figs. 2 and 3 ). The high values of the determination coefficient $\left(\mathrm{R}^{2}\right)$ demonstrated a good fitting of the experimental data to the model proposed (Figs. 2 and 3). The cellulose, hemicellulose, and lignin concentrations in the solid phase of the raw substrate were decreased with an increase in the specific energy input (Figs. 4, 5, and 6), which means that they have been dissolved. The maximum decrease in the concentration of cellulose was significantly higher than the observed decreases in hemicellulose and lignin, whose values were by $33.6 \%, 27.2 \%$, and $14.0 \%$, respectively $(p<0.05)$.

Taking into account other works [23-25], it could be assumed that ultrasonic pretreatment enhances delignification and solubilization of the plant materials. In a liquid medium, ultrasonication breaks the bonds between lignin monomers to breakdown the lignin structure $[9,23,26]$. The cavitation process takes place most actively at the liquid-solid interphase, leading to contracting, expanding, and finally fractionating of the lignocellulosic biomass $[27,28]$. The partial decomposition of lignin facilitates enzymes to access the glycoside bonds of polysaccharides, leading to increasing bioconversion of the plant substrate [29]. Garcia et al. [30] observed decreasing contents of hemicellulose in the solid samples of olive tree pruning residues treated with ultrasounds over $30 \mathrm{~min}$ and 
Fig. 2 Effect of UP on COD solubilization of the homogenized substrate, mixture of homogenized substrate and anaerobic sludge, and digestate

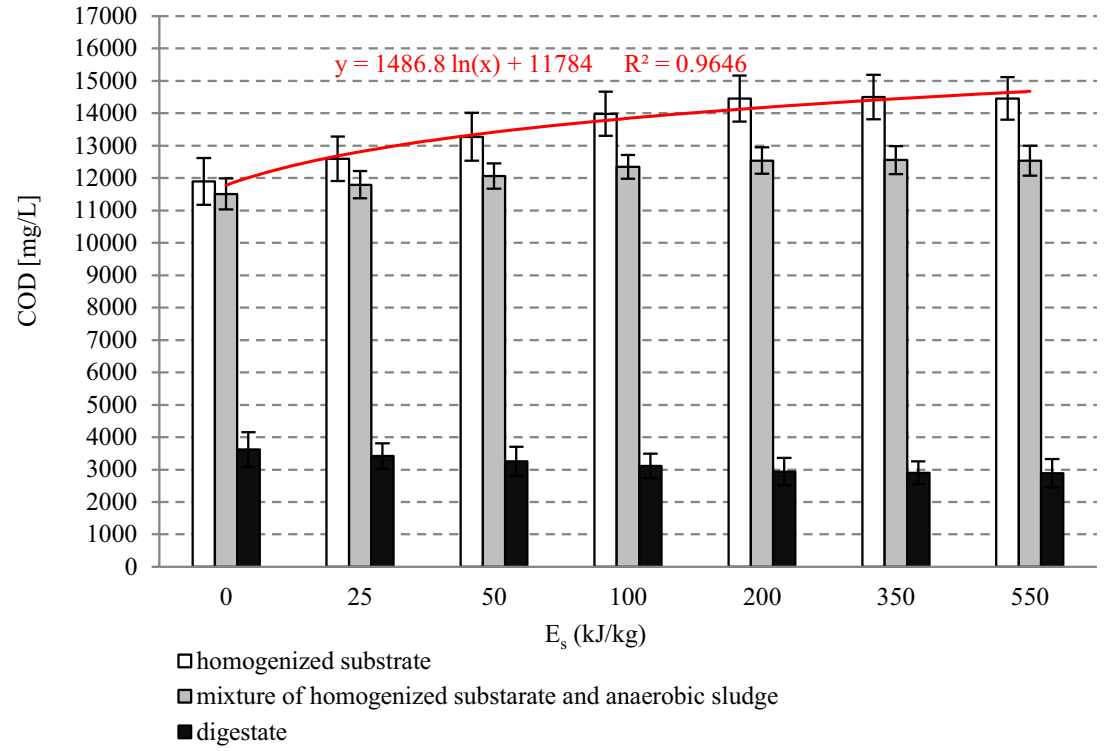

increasing of hemicelluloses and lignin in the liquid fraction. According to the literature, sonication enhanced degradation of lignin by $10 \%$; however, it did not affect the fibrillary structure of cellulose $[24,25,30,31]$. Sul'man et al. [28] demonstrated the effects of UP $\left(368 \mathrm{~W} / \mathrm{cm}^{2}, 30 \mathrm{kHz}\right)$ on cellulose and lignin degradation of sunflower husk biomass when the treatment time was no longer than $15 \mathrm{~min}$. After that time, their contents increased gradually, which was associated with the initiation of the anew lignin polymerization process. In our study, we also observed the increasing concentration of lignin in the solid phase of the substrate when the irradiation time was higher than $16 \mathrm{~min}$. Generally, higher energy inputs lead to the formation of large biomass particles due to reflocculation process; in contrast, low energy inputs and short

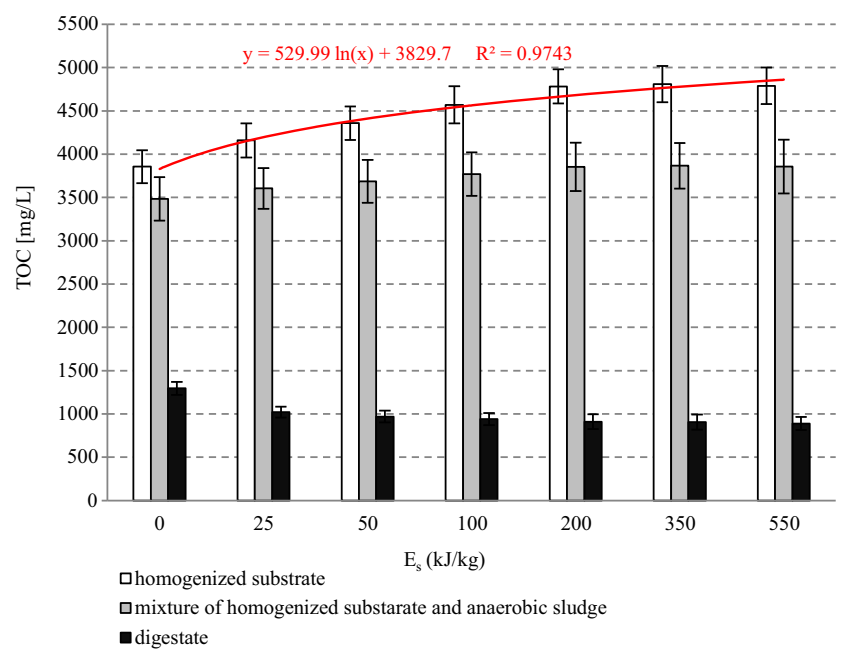

Fig. 3 Effect of UP on TOC solubilization of the homogenized substrate, mixture of homogenized substrate and anaerobic sludge, and digestate pretreatment time only enhance biomass deagglomeration instead of its solubilization [32,33]. An increase in the intensity of ultrasound enhanced the polysaccharide extraction from lignocellulosic biomass and enhanced the degradation of compounds with high molecular weight, e.g., lignin [28]. According to Rehman et al. [34], the efficiency of ultrasonic pretreatment increases with energy input increasing until the increasing number of cavitational bubbles is as much that starts to decrease energy transfer to the liquid. In our study, the optimum $E_{s}$ for pretreatment of the mixture of Sida hermaphrodita and cattle manure at which the most complete destruction of the substrate was achieved ranged from 200 to $350 \mathrm{~kJ} / \mathrm{kg}$.

\section{Effect of UP on Biogas Production}

Figure 7 illustrates the experimental results of the batch anaerobic biodegradability tests. The statistical analyses allowed the calculation of the determination coefficient $\left(\mathrm{R}^{2}\right)$, which was higher than 0.95 in estimation of the methane yield and as low as 0.87 in biogas yield analysis. The raw substrate without pretreatment showed the biogas and methane yields of $341.4 \mathrm{~L} / \mathrm{kg}$ VS and $139.8 \mathrm{~L} / \mathrm{kg}$ VS, respectively. Ultrasonic pretreatment had significant effect on the biogas yield $(p<0.05)$ when the specific energy input $\left(E_{s}\right)$ ranges between 100 and $550 \mathrm{~kJ} / \mathrm{kg}$. Lower energy inputs had no significant effects on biogas yield. The highest biogas production of $567.1 \mathrm{~L} / \mathrm{kg}$ VS was achieved with the highest specific energy input; however, there was no difference when $\mathrm{E}_{\mathrm{S}}$ ranges from 100 to $550 \mathrm{~kJ} / \mathrm{kg}$. In turn, sonication of the raw substrate had significant effect on methane yield under all pretreatment conditions $(p<0.05)$. The highest methane yields ranged between 318.0 and $337.9 \mathrm{~L} / \mathrm{kg} \mathrm{VS}$ with $E_{S}$ of $200-550 \mathrm{~kJ} / \mathrm{kg}(p>0.05)$. 
Table 3 Carbon compound concentrations in the solid and liquid phase of homogenized substrate

\begin{tabular}{|c|c|c|c|c|c|c|c|c|c|}
\hline \multirow{2}{*}{$\begin{array}{l}E_{S} \\
(\mathrm{~kJ} / \\
\mathrm{kg})\end{array}$} & \multicolumn{3}{|c|}{ Total carbon (TC) } & \multicolumn{3}{|c|}{ Total organic carbon (TOC) } & \multicolumn{3}{|c|}{ Inorganic carbon (IC) } \\
\hline & $\begin{array}{l}\text { Homogenized } \\
\text { substrate } \\
\text { Concentration }\end{array}$ & $\begin{array}{l}\text { Solid } \\
\text { fraction } \\
\text { (L) }\end{array}$ & $\begin{array}{l}\text { Liquid } \\
\text { fraction }\end{array}$ & $\begin{array}{l}\text { Homogenized } \\
\text { substrate }\end{array}$ & $\begin{array}{l}\text { Solid } \\
\text { fraction }\end{array}$ & $\begin{array}{l}\text { Liquid } \\
\text { fraction }\end{array}$ & $\begin{array}{l}\text { Homogenized } \\
\text { substrate }\end{array}$ & $\begin{array}{l}\text { Solid } \\
\text { fraction }\end{array}$ & $\begin{array}{l}\text { Liquid } \\
\text { fraction }\end{array}$ \\
\hline 0 & $21.67 \pm 3.12$ & $16.5 \pm 2.11$ & $5.17 \pm 0.41$ & $18.78 \pm 0.73$ & $14.92 \pm 0.49$ & $3.86 \pm 0.18$ & $2.89 \pm 0.45$ & $1.58 \pm 0.19$ & $1.31 \pm 0.31$ \\
\hline 25 & $21.51 \pm 2.99$ & $16.07 \pm 1.88$ & $5.44 \pm 0.39$ & $18.77 \pm 2.09$ & $14.61 \pm 1.71$ & $4.16 \pm 0.20$ & $2.74 \pm 0.39$ & $1.46 \pm 0,24$ & $1.28 \pm 0.18$ \\
\hline 50 & $21.08 \pm 3.92$ & $15.45 \pm 2.72$ & $5.63 \pm 0.70$ & $18.61 \pm 2.41$ & $14.25 \pm 2.04$ & $4.36 \pm 0.19$ & $2.47 \pm 0.77$ & $1.20 \pm 0.37$ & $1.27 \pm 0.32$ \\
\hline 100 & $21.12 \pm 3.07$ & $15.26 \pm 2.03$ & $5.86 \pm 0.63$ & $18.71 \pm 3.01$ & $14.14 \pm 2.11$ & $4.57 \pm 0.23$ & $2.41 \pm 0.28$ & $1.12 \pm 0.11$ & $1.29 \pm 0.16$ \\
\hline 200 & $20.92 \pm 2.96$ & $14.83 \pm 1.99$ & $6.09 \pm 0.71$ & $18.53 \pm 2.60$ & $13.75 \pm 1.93$ & $4.78 \pm 0.20$ & $2.39 \pm 0.52$ & $1.08 \pm 0.37$ & $1.31 \pm 0.23$ \\
\hline 350 & $20.59 \pm 4.01$ & $14.46 \pm 3.05$ & $6.13 \pm 0.83$ & $18.19 \pm 4.02$ & $13.38 \pm 3.01$ & $4.81 \pm 0.21$ & $2.40 \pm 0.51$ & $1.08 \pm 0.16$ & $1.32 \pm 0.37$ \\
\hline 500 & $20.65 \pm 3.64$ & $14.55 \pm 2.61$ & $6.10 \pm 0.88$ & $18.52 \pm 3.17$ & $13.73 \pm 2.19$ & $4.79 \pm 0.15$ & $2.13 \pm 0.57$ & $0.82 \pm 0.11$ & $1.31 \pm 0.40$ \\
\hline
\end{tabular}

Significant improvement in methane yield by ultrasound was observed by several researchers [18, 33, 35]. According to Schroyen et al. [36], the methane production from lignocellulosic crops was in the range of 170 to $390 \mathrm{~L} / \mathrm{kg}$ VS and substrate composition, especially the lignin content, highly affected the results of methane production [37, 38]. Under the studied conditions, maximum methane yield was lower than the maximum values for lignocellulosic materials. However, ultrasonic pretreatment enhanced biogas evolution by $142 \%$. Similarly, Castrillón et al. [33] observed increase in biogas production from cattle manure pretreated by ultrasound by $121 \%$. Pretreatment of waste activated sludge by ultrasound enhanced the biogas production by $172.56 \%$ [39]. In turn, Pérez-Rodríguez et al. [24] observed that the sonication of corn cob did not allow enhancing the methane yield.

Methane concentration in biogas increased due to pretreatment, and the increase was found to be significant with respect to the level achieved in the substrate without UP (Fig. 8). Maximum methane concentration of $59.6 \%$ was noted with the highest specific energy input; however, there was no difference

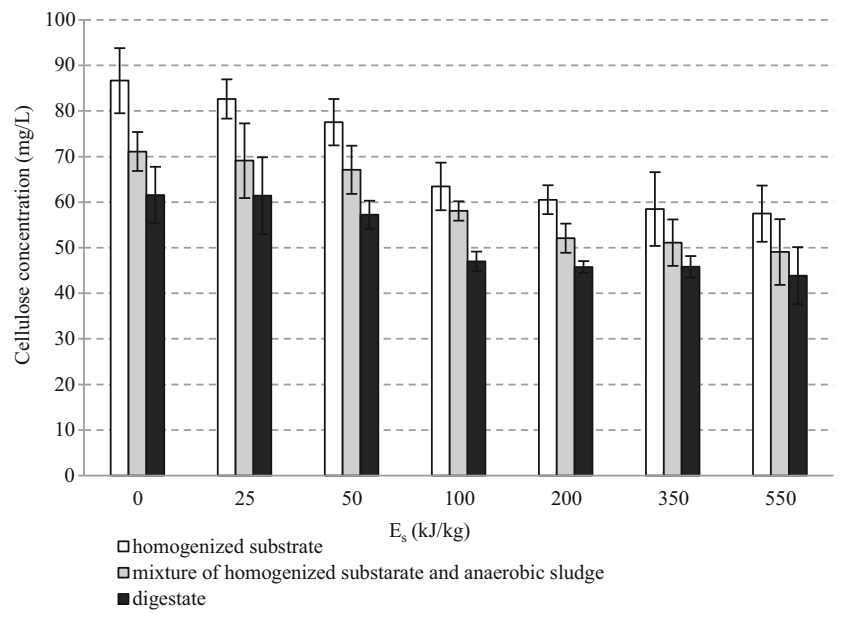

Fig. 4 Effect of UP on cellulose concentrations in the solid phase of the homogenized substrate, mixture of homogenized substrate and anaerobic sludge, and digestate in methane content in biogas $(p>0.05)$ when ultrasonic energy input ranges from 200 to $350 \mathrm{~kJ} / \mathrm{kg}$. It is in contrast to the findings of other researchers, who did not observe the increase in methane concentration in biogas due to UP $[18,33,40]$.

The mathematical formula of biogas yield (3) from lignocellulosic agricultural feedstock is characterized by a standard error of \pm 12.36 and represent about $95.84 \%$ of changes observed in the biogas production process (coefficient of determination $\mathrm{R}^{2}=0.9584$ ). The formula of methane yield (4) is characterized by a standard error of \pm 10.63 and represent about $96.45 \%$ of changes observed in the process (coefficient of determination $\mathrm{R}^{2}=0.9645$ ).

$$
\begin{aligned}
B(\mathrm{~L} / \mathrm{kg} \mathrm{VS}) & =0.081 E_{s}-9.168 C+1.709 H-4.655 L-0.056 \text { TOC } \\
& +1373.957 \\
M(\mathrm{~L} / \mathrm{kg} \mathrm{VS}) & =0.1403 E_{s}-3.1407 C+0.6505 H-7.5883 L-0.011 \text { TOC } \\
& +816.6387
\end{aligned}
$$

where $B$ is the predicted yield of biogas in $\mathrm{L} / \mathrm{kg} \mathrm{VS}, M$ is the predicted yield of methane in $\mathrm{L} / \mathrm{kg} \mathrm{VS}, E_{S}$ is the specific

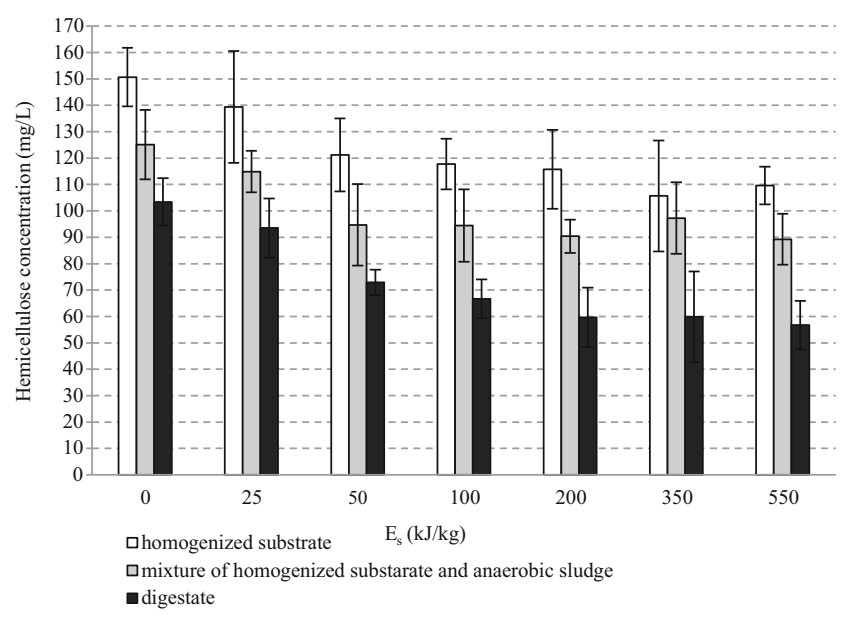

Fig. 5 Effect of UP on hemicellulose concentrations in the solid phase of the homogenized substrate, mixture of homogenized substrate and anaerobic sludge, and digestate 


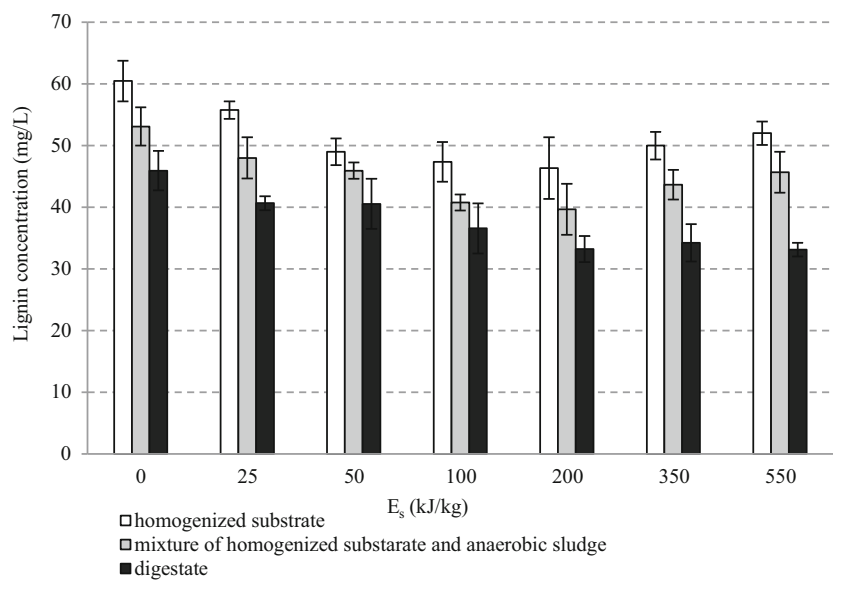

Fig. 6 Effect of UP on lignin concentrations in the solid phase of the homogenized substrate, mixture of homogenized substrate and anaerobic sludge, and digestate

energy input of ultrasonication in $\mathrm{kJ} / \mathrm{kg}, C$ is the cellulose content in the solid fraction of lignocellulosic biomass in $\mathrm{mg} / \mathrm{L}, H$ is the hemicellulose content in the solid fraction of lignocellulosic biomass in $\mathrm{mg} / \mathrm{L}, L$ is the lignin content in the solid fraction of lignocellulosic biomass in $\mathrm{mg} / \mathrm{L}$, and TOC is the total organic carbon concentration in the soluble fraction of lignocellulosic biomass in $\mathrm{mg} / \mathrm{L}$.

The effectiveness of ultrasonic pretreatment of agricultural biomass is strongly depending on the feedstock characteristics, and these formulas allow for basic prediction of biogas and methane yield from lignocellulosic biomass pretreated with ultrasound and does not require a large number of predictor data.

\section{Effect of UP on Anaerobic Digestate Characteristic}

In our study, the reduction in TOC, COD, and VS (as \% TS) was observed (Figs. 2, 3, and 9) which was the result

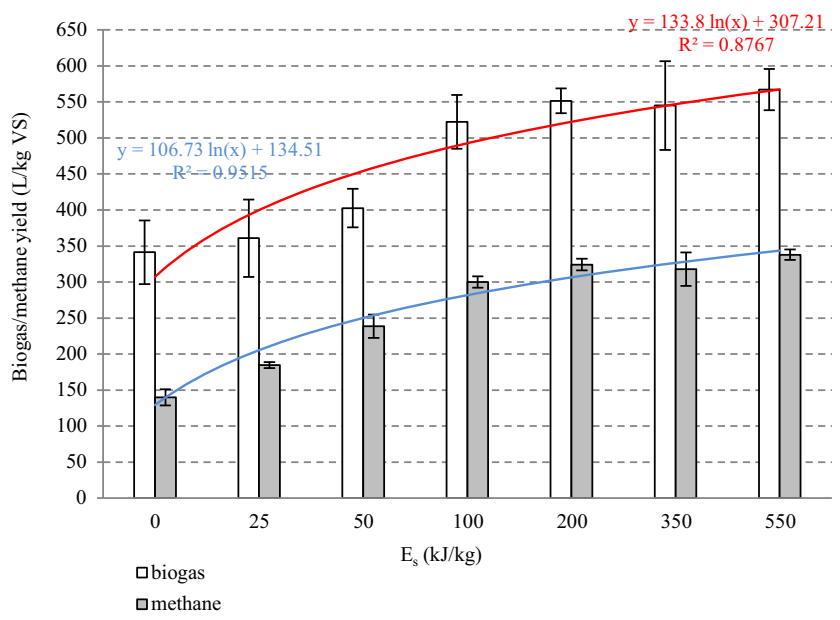

Fig. 7 Effect of UP on biogas and methane yield

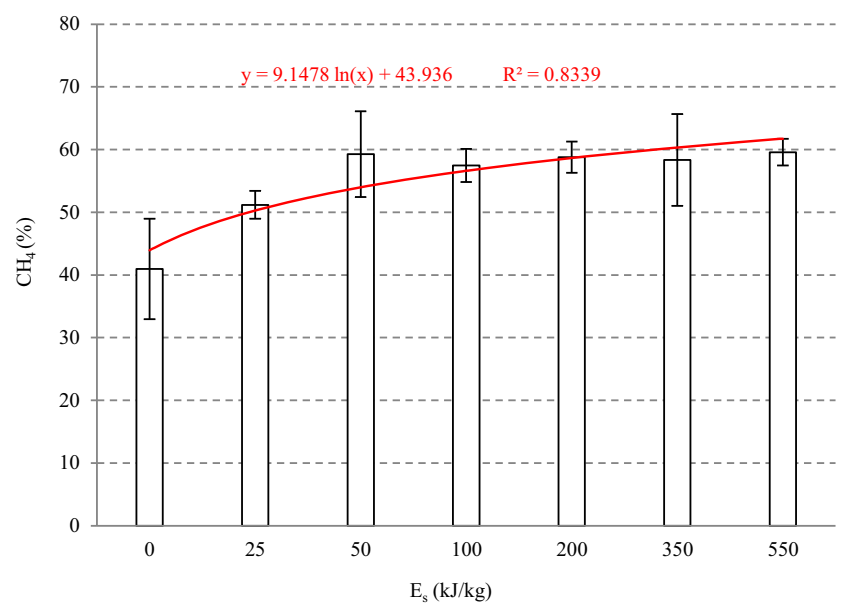

Fig. 8 Effect of UP on methane concentration in biogas

of biogas production. When ultrasonic pretreatment was used, the TOC reduction ranged from $71.7 \%\left(\mathrm{E}_{\mathrm{s}}\right.$ of $25 \mathrm{~kJ} /$ $\mathrm{kg}$ ) to $76.6 \%\left(\mathrm{E}_{\mathrm{s}}\right.$ of $550 \mathrm{~kJ} / \mathrm{kg}$ ) (Fig. 2). For the raw substrate, the TOC reduction achieved $62.8 \%(p<0.05)$. The COD reduction ranged from 70.9 to $76.9 \%$ when the substrate was pretreated with ultrasound and $68.5 \%$ without pretreatment $(p<0.05 \%)$, (Fig. 3). They corresponded to VS reduction, which was the highest with ultrasonic energy input of $550 \mathrm{~kJ} / \mathrm{kg}$ (Fig. 9). However, no significant differences in VS reduction were observed in samples pretreated with ultrasound and without pretreatment $(p>0.05)$. Zeynali et al. [35] noted significant effects of ultrasounds on TS and VS reduction in fruit and vegetable wholesale market waste samples. They obtained $63 \%$ of VS and $58 \%$ of TS reductions in sonicated samples, which were respectively $8 \%$ and $12 \%$ higher than in samples without pretreatment.

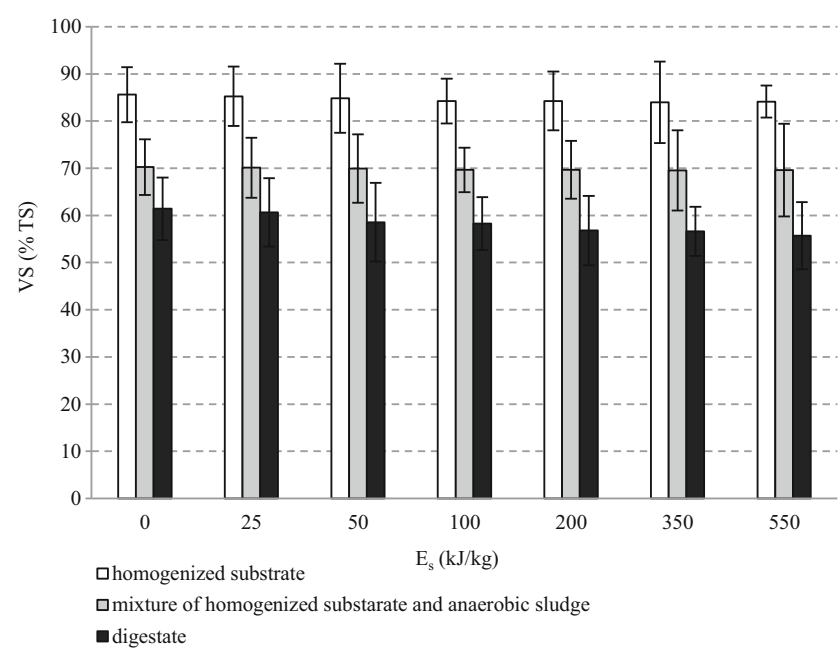

Fig. 9 Effect of UP on VS concentration in the homogenized substrate, mixture of homogenized substrate and anaerobic sludge, and digestate 
Table 4 Energy gain assessment of the anaerobic digestion of homogenized substrate for different UP conditions

\begin{tabular}{lllll}
\hline Variant & $\begin{array}{l}\text { Energy output } E_{\text {out }} \\
(\mathrm{kJ} / \mathrm{kg} \text { VS) }\end{array}$ & $\begin{array}{l}\text { Net energy output } E_{\text {nout }} \\
(\mathrm{kJ} / \mathrm{kg} \mathrm{VS})\end{array}$ & $\begin{array}{l}\text { Energy input } E_{S} \\
(\mathrm{~kJ} / \mathrm{kg} \mathrm{VS})\end{array}$ & $\begin{array}{l}\text { Net energy gain } E_{\text {net }} \\
(\mathrm{kJ} / \mathrm{kg} \mathrm{VS})\end{array}$ \\
\hline 1 & $1282 \pm 102$ & 0 & 0 & 0 \\
2 & $1694 \pm 37$ & $412 \pm 140$ & $407 \pm 67$ & $5 \pm 0.75$ \\
3 & $2188 \pm 149$ & $906 \pm 251$ & $813 \pm 115$ & $93 \pm 26$ \\
4 & $2752 \pm 72$ & $1470 \pm 174$ & $1627 \pm 230$ & $-157 \pm 14$ \\
5 & $2972 \pm 74$ & $1690 \pm 176$ & $3254 \pm 460$ & $-1564 \pm 234$ \\
6 & $2915 \pm 213$ & $1633 \pm 315$ & $6508 \pm 920$ & $-4875 \pm 633$ \\
7 & $3098 \pm 65$ & $1816 \pm 167$ & $13,017 \pm 1840$ & $-12,831 \pm 1790$ \\
\hline
\end{tabular}

$E_{\text {out }}$ energy output generated from biogas production calculated according to Eq. 2, $E_{\text {nout }}$ net energy output calculated by subtracting $E_{(o u t)}$ in $n$-variant and $E_{(o u t)}$ in variant $1, E_{s}$ specific energy input calculated according to Eq. $1, E_{n e t}$ net energy gain calculated by subtracting $E_{\text {nout }}$ in $n$-variant and $E_{s}$ in $n$-variant

\section{Energy Balance of UP}

The energy gain assessment of anaerobic digestion of lignocellulosic agricultural feedstock pretreated with ultrasonic is presented in Table 4. The net energy output gained from methane production was increased with the specific energy input increasing, because UP enhanced the biogas yield. However, only ultrasonic pretreatments with $E_{s}$ between 25 and $50 \mathrm{~kJ} / \mathrm{kg}$ led to the positive net energy gain. In other variants (from 4 to 7 ), the negative energy balances were noted because the amount of energy inputs $\left(E_{s}\right)$ used for irradiation of the substrate far exceeded the amount of energy produced from biogas. It could be states that from economic point of view, ultrasonic pretreatment is not suitable for lignocellulosic agricultural biomass pretreatment.

\section{Conclusions}

Ultrasonication of Sida hermaphrodita mixed with cattle manure resulted in significant effects on organic matter solubilization by $21.9 \%$ as COD and by $24.7 \%$ as TOC with the specific energy input ranged from 200 to $550 \mathrm{~kJ} / \mathrm{kg}$. The maximum decrease in the concentration of cellulose, hemicellulose, and lignin in the solid phase of the raw substrate was $33.6 \%, 27.2 \%$, and $14.0 \%$, respectively. Significant improvement in biogas/methane yield by ultrasonic pretreatment was observed. The methane yields ranging between 318.0 and $337.9 \mathrm{~L} / \mathrm{kg}$ VS with $E_{s}$ of $200-550 \mathrm{~kJ} / \mathrm{kg}$ were achieved. Ultrasonic pretreatment increased the net energy output gained from methane production. However, the overall process results were energetically favorable only when $E_{S}$ ranged from 25 to $50 \mathrm{~kJ} / \mathrm{kg}$, which indicated that the increased methane yield by UP did not compensate the energy consumption for irradiation.
Funding Information The work was supported by the National Centre for Research and Development, Poland [grant number BIOSTRATEG 1/270745/2/NCBR/2015] entitled "Dietary, power, and economic potential of Sida hermaphrodita cultivation on fallow land" (acronym SIDA).

Open Access This article is licensed under a Creative Commons Attribution 4.0 International License, which permits use, sharing, adaptation, distribution and reproduction in any medium or format, as long as you give appropriate credit to the original author(s) and the source, provide a link to the Creative Commons licence, and indicate if changes were made. The images or other third party material in this article are included in the article's Creative Commons licence, unless indicated otherwise in a credit line to the material. If material is not included in the article's Creative Commons licence and your intended use is not permitted by statutory regulation or exceeds the permitted use, you will need to obtain permission directly from the copyright holder. To view a copy of this licence, visit http://creativecommons.org/licenses/by/4.0/.

\section{References}

1. Faaij APC (2018) Securing sustainable resource availability of biomass for energy applications in Europe, review of recent literature. http://bioenergyeurope.org/wp-content/uploads/2018/11/ Bioenergy-Europe-EU-Biomass-Resources-Andr\%C3\%A9-FaaijFinal.pdf

2. Renewable Energy Directive (RED) 2009/EC/28 EC (2009)

3. Stolarski MJ, Krzyżaniak M, Warmiński K, Tworkowski J, Szczukowski JS, Olba-Zięty E, Gołaszewski J (2017) Energy efficiency of perennial herbaceous crops production depending on the type of digestate and mineral fertilizers. Energy Educ Sci Tech Part A: Energy Sci Res 134:50-60

4. Nabel M, Temperton VM, Poorter H, Lücke A, Jablonowski ND (2016) Energizing marginal soils - the establishment of the energy crop Sida hermaphrodita as dependent on digestate fertilization, NPK, and legume intercropping. Biomass Bioenergy 87:9-16

5. Oleszek M, Matyka M, Lalak J, Tys J, Paprota E (2013) Characterization of Sida hermaphrodita as a feedstock for anaerobic digestion process. J Food Agric Environ 11:1839-1841

6. Bharathiraja B, Sudharsana T, Jayamuthunagai J, Praveenkumar R, Chozhavendhan S, Iyyappan J (2018) Biogas production - a review on composition, fuel properties, feed stock and principles of anaerobic digestion. Renew Sust Energ Rev 90:570-582 
7. Zheng Y, Zhao J, Xu F, Li Y (2014) Pretreatment of lignocellulosic biomass for enhanced biogas production. Prog Energy Combust Sci 42:35-53

8. Kumari D, Singh R (2018) Pretreatment of lignocellulosic wastes for biofuel production: a critical review. Renew Sust Energ Rev 90: 877-891

9. You Z, Pan S-Y, Sun N, Kim H, Chiang P-C (2019) Enhanced corn stover fermentation for biogas production by $\mathrm{NaOH}$ pretreatment with $\mathrm{CaO}$ additive and ultrasound. J Clean Prod 238:117813

10. Zheng Y, Shi J, Tu M, Cheng YS (2017) Principles and development of lignocellulosic biomass pretreatment for biofuels (chapter one). Adv Bioenergy 2:1-68

11. Menon V, Rao M (2012) Trends in bioconversion of lignocellulose: biofuels, platform chemicals \& biorefinery concept. Prog Energy Combust Sci 38:522-555

12. Cesaro A, Belgiorno V (2014) Pretreatment methods to improve anaerobic biodegradability of organic municipal solid waste fractions. Chem Eng J 240:24-37

13. Amin FR, Khalid H, Zhang H, Rahman S, Zhang R, Liu G, Chen C (2017) Pretreatment methods of lignocellulosic biomass for anaerobic digestion. AMB Express 7:72

14. Zou S, Wang X, Chen Y, Wan H, Feng Y (2016) Enhancement of biogas production in anaerobic co-digestion by ultrasonic pretreatment. Energy Convers Manag 112:226-235

15. Avvaru B, Venkateswaran N, Uppara P, Iyengar SB, Katti SS (2018) Current knowledge and potential applications of cavitation technologies for the petroleum industry. Ultrason Sonochem 42: 493-507

16. Harris PW, McCabe BK (2015) Review of pre-treatments used in anaerobic digestion and their potential application in high-fat cattle slaughterhouse wastewater. Appl Energy 155:560-575

17. Carrère H, Dumas C, Battimelli A, Batstone DJ, Delgenès JP, Steyer JP, Ferrer I (2010) Pretreatment methods to improve sludge anaerobic degradability: a review. J Hazard Mater 183:1-15

18. Neumann P, González Z, Vidal G (2017) Sequential ultrasound and low-temperature thermal pretreatment: process optimization and influence on sewage sludge solubilization, enzyme activity and anaerobic digestion. Bioresour Technol 234:178-187

19. Carrere H, Antonopoulou G, Affes R, Passos F, Battimelli A, Lyberatos G, Ferrer I (2016) Review of feedstock pretreatment strategies for improved anaerobic digestion: from lab-scale research to full-scale application. Bioresour Technol 199:386-397

20. Fumo N, Rafe BMA (2015) Regression analysis for prediction of residential energy consumption. Renew Sust Energ Rev 47:332343

21. Silhavy R, Silhavy P, Zdenka P (2017) Analysis and selection of a regression model for the use case points method using a stepwise approach. J Syst Softw 125:1-14

22. Kokaly RF, Clark RN (1999) Spectroscopic determination of leaf biochemistry using band-depth analysis of absorption features and stepwise multiple linear regression. Remote Sens Environ 67:267287

23. Hassan S, Williams GA, Jaiswal AK (2018) Emerging technologies for the pretreatment of lignocellulosic biomass. Bioresour Technol 262:310-318

24. Pérez-Rodríguez N, García-Bernet D, Domínguez JM (2016) Effects of enzymatic hydrolysis and ultrasounds pretreatments on corn cob and vine trimming shoots for biogas production. Bioresour Technol 221:130-138
25. Iskalieva A, Yimmou BM, Gogate PR, Horvath M, Horvath PG, Csoka L (2012) Cavitation assisted delignification of wheat straw: a review. Ultrason Sonochem 19:984-993

26. Tian SQ, Wang ZY, Fan ZL, Zuo LL (2012) Comparison of ultrasonic and $\mathrm{CO}_{2}$ laser pretreatment methods on enzyme digestibility of corn stover. Int J Mol Sci 13:4141-4152

27. Velmurugan R, Muthukumar K (2012) Sono-assisted enzymatic saccharification of sugar cane bagasse for bioethanol production. Biochem Eng J 63:1-9

28. Sul'man EM, Sul'man MG, Prutenskaya EA (2011) Effect of ultrasonic pretreatment on the composition of lignocellulosic material in biotechnological processes. Catal Ind 3:28-33

29. Madison MJ, Coward-Kelly G, Liang C, Karim MN, Falls M, Holtzapple T (2017) Mechanical pretreatment of biomass - part I: acoustic and hydrodynamic cavitation. Biomass Bioenergy 98: 135-141

30. García A, González Alriols M, Llano-Ponte R, Labidi J (2011) Ultrasound-assisted fractionation of the lignocellulosic. Bioresour Technol 102:6326-6330

31. Yu J, Zhang J, He J, Liu Z, Yu Z (2009) Combinations of mild physical or chemical pretreatment with biological pretreatment for enzymatic hydrolysis of rice hull. Bioresour Technol 100:903-908

32. Quiroga G, Castrillón L, Fernández-Nava Y, Marañón E, Negral L, Rodríguez-Iglesias J, Ormaechea P (2014) Effect of ultrasound pretreatment in the anaerobic co-digestion of cattle manure with food waste and sludge. Bioresour Technol 154:74-79

33. Castrillón L, Fernández-Nava Y, Ormaechea P, Marañón E (2011) Optimization of biogas production from cattle manure by pretreatment with ultrasound and co-digestion with crude glycerin. Bioresour Technol 102:7845-7849

34. Rehman MSU, Kim I, Chisti Y, Han JI (2013) Use of ultrasound in the production of bioethanol from lignocellulosic biomass. Energy Educ Sci Tech Part A: Energy Sci Res 30:1391-1410

35. Zeynali R, Khojastehpour M, Ebrahimi-Nik M (2017) Effect of ultrasonic pre-treatment on biogas yield and specific energy in anaerobic digestion of fruit and vegetable wholesale market wastes. Sustain Environ Res 27:259-264

36. Schroyen M, Vervaeren H, Van Hulle SWH, Raes K (2014) Impact of enzymatic pretreatment on corn stover degradationand biogas production. Bioresour Technol 173:59-66

37. Menardo S, Airoldi G, Cacciatore V, Balsari P (2015) Potential biogas and methane yield of maize stover fractions and evaluation of some possible stover harvest chains. Bioresour Technol 129: 352-359

38. Dandikas V, Heuwinkel H, Lichti F, Drewes JE, Koch K (2014) Correlation between biogas yield and chemical composition of energy crops. Bioresour Technol 174:316-320

39. Zhang Z, Zhang L, Zhou Y, Chen J, Liang Y, Wei L (2013) Pilotscale operation of enhanced anaerobic digestion of nutrientdeficient municipal sludge by ultrasonic pretreatment and codigestion of kitchen garbage. J Environ Chem Eng 1:73-78

40. Bougrier C, Albasi C, Delgenès JP, Carrère H (2006) Effect of ultrasonic, thermal and ozone pre-treatments on waste activated sludge solubilisation and anaerobic biodegradability. Chem Eng Process 45:711-718

Publisher's Note Springer Nature remains neutral with regard to jurisdictional claims in published maps and institutional affiliations. 